\title{
INVESTIGATIONS INTO THE EFFECT OF HOT, DRY MICROCLIMATE ON PERIPHERAL CIRCULATION, ETC., IN ARTHRITIC PATIENTS
}

\author{
BY \\ GUNNAR EDSTRÖM, G. LUNDIN, and T. WRAMNER \\ From the Rheumatism Department, University of Lund, Sweden
}

During the last six years one of the wards of the University Hospital in Lund has been used as a climatic laboratory. The temperature of the air in the room can be adjusted between what is normal outdoor temperature in south Sweden-in the winter below zero-and $40^{\circ} \mathrm{C}$., the relative humidity between 30 per cent. and complete saturation, and both these factors can be kept constant at the level desired with a very small range of variation.

\section{The Arrangement of the Ward}

No expensive arrangements have been made. An ordinary sick ward with space for two beds has been provided with double walls, double ceilings and double floors, with free air-space between the two layers. The old double window has been furnished with another two inner sashes. The space between the old door of the room and that built in the new wall has been arranged as an air-lock, where the staff and the visitors stop for a while to regulate the temperature of their clothes before entering the ward.

The air-jacket within the double walls, sashes, floors, and ceilings, and the air in the lock, are electrically heated to the required temperature and set in motion by a fan.

The air for the laboratory itself is drawn through an air-conditioning plant in the corridor outside the room; it is blown into the laboratory through a central grating in the inner ceiling, surplus air being afterwards pressed out of the room through exhaust conduits that run round the edge of the inner ceiling.

If the regulating thermostats-one for the air jacket, the other for the air of the room-are set at the same temperature, which has always been done in these investigations, the result will be absence of convection currents and very little air movement in the lower part of the room. So-called draughts will be entirely excluded.

The relative air humidity in the room is adjusted by means of a psychrostat. (For a more detailed description, see Edström, 1944.)

\section{The Tolerated Temperature}

After a period of testing to see how the patients would tolerate different temperatures and humidities, we came to the same result as Gagge and others (1937), viz. that $32^{\circ} \mathrm{C} .\left(89 \cdot 6^{\circ} \mathrm{F}\right.$.) was agreeable and that under this temperature the patients were not troubled by any perspiration worth mentioning if the relative humidity of the air was kept below 50 per cent. In the subsequent tests we accordingly stopped at a temperature of $32^{\circ} \mathrm{C}$. and a relative humidity of 35 per cent. Under these circumstances sixteen patients with rheumatic fever in a rather late stage, and eighteen patients with rheumatoid arthritis have been treated, each of them for about a hundred days on an average.

\section{The Investigation}

The effects on these patients of their stay in this dry, hot microclimate for so long a time-they were not allowed to leave the room during the whole of their stay in the "laboratory"-were then investigated.

The skin temperature of the patients was determined with a thermo-couple of copper and constantan. At the soldered joint intended for application to the skin the filaments intersected one another at right angles. At the intersection they were soldered. This soldered junction was exactly in the middle of a ring of ebonite, the upper part of which was continued in a handle of ebonite. The second soldered joint, which during the investigations should be at a constant known temperature, was fixed at the mercury-receptacle of a mercury-thermometer having $0.05^{\circ} \mathrm{C}$. graduations and placed in a thermos flask containing water at about $30^{\circ} \mathrm{C}$. $\left(86^{\circ}\right.$ F. $)$ For registration of the electromotive power a multiflex galvanometer was used, so graduated that every line on the scale corresponded to $0.05^{\circ} \mathrm{C}$., which was controlled by repeated calibrations. When measurements were 
being taken the thermo-couple was always placed on the skin for exactly ten seconds.

As a rule, at every investigation the skin temperature was measured once a minute, at least five times, on the following parts of the body: the volar side of the distal phalanx of the thumb, the middle of the dorsal side of the upper arm, and the middle of the soft part of the cheek. The thermo-couple was placed exactly on the same place and under the same pressure at every measuring (Ipsen, 1936). When the effect of cold was being studied one of the hands of the patient was placed in ice-water. When the effect of amyl nitrite was being studied the patient inhaled this substance.

For determining the oxygen content of the blood van Slyke and Neill's monometric method was employed (van Slyke and Neill, 1924; Edström, 1943). Measurement of the cardiac output was done by the acetylene method (Grollman, 1932). For the determination of the basal metabolic rate the method with a Douglas bag was used (Douglas, 1911).

All these determinations were carried out at eight o'clock in the morning, immediately after the patients had awakened and while they were still resting and had not had anything to eat or drink.

\section{Results}

It is evident from the investigation that, under an ordinary room temperature of $20^{\circ} \mathrm{C}$. and a normal relative humidity of the air of about 50 to 60 per cent., these patients in hospital-especially most cases of rheumatoid arthritis-show a relatively low skin-temperature on the distal parts of the extremities -lower than that of normal healthy persons (Edström, 1940 ; Wright and Pemberton, 1930)-and that the difference between the skin-temperature of these parts and of the trunk is very high (Tables 1 and 2, Figs. 1, 2, and 3).

\section{TABLE 1}

THE ARITHMETIC MEAN OF TEMPERATURE READINGS ON THE THUMB BEFORE AND DURING TREATMENT IN THE CLIMATIC LABORATORY

\begin{tabular}{c|c|c}
\hline Patient & Before $\left({ }^{\circ} \mathrm{C}.\right)$ & During $\left({ }^{\circ} \mathrm{C}.\right)$ \\
\hline 1 & $29.2 \pm 0.6$ & $32.9 \pm 0.3$ \\
2 & $30.8 \pm 0.3$ & $33.0 \pm 0.2$ \\
3 & $30.5 \pm 0.8$ & $35.1 \pm 0.5$ \\
4 & $29.1 \pm 0.2$ & $35.2 \pm 0.2$ \\
5 & $29.6 \pm 0.2$ & $35.3 \pm 0.1$ \\
6 & $28.0 \pm 0.6$ & $32.1 \pm 0.2$ \\
7 & $31.5 \pm 0.8$ & $34.1 \pm 0.6$ \\
8 & $27.0 \pm 0.3$ & $33.9 \pm 0.5$ \\
9 & $26.8 \pm 0.4$ & $32.8 \pm 0.2$ \\
10 & $30.1 \pm 0.3$ & $35.1 \pm 0.2$ \\
\hline
\end{tabular}

The arithmetic mean of all readings of all patients:

Before treatment in the climatic laboratory: $28 \cdot 9 \pm 0 \cdot 4$. During treatment in the climatic laboratory: $34 \cdot 0 \pm 0 \cdot 3$. Difference: $5 \cdot 1 \pm 0 \cdot 5$.
TABLE 2

THE ARITHMETIC MEAN OF TEMPERATURE READINGS ON THE UPPER ARM BEFORE AND DURING TREATMENT. IN THE CLIMATIC LABORATORY

\begin{tabular}{|c|c|c|}
\hline Patient & Before $\left({ }^{\circ} \mathrm{C}.\right)$ & During $\left({ }^{\circ} \mathrm{C}.\right)$ \\
\hline $\begin{array}{r}1 \\
2 \\
3 \\
4 \\
5 \\
6 \\
7 \\
8 \\
9 \\
10\end{array}$ & $\begin{array}{l}30.3 \pm 0.3 \\
30.5 \pm 0.3 \\
30.0 \pm 0.2 \\
30.0 \pm 0.3 \\
31.3 \pm 0.1 \\
31.0 \pm 0.5 \\
31.1 \pm 0.8 \\
28.3 \pm 0.9 \\
31.8 \pm 0.3 \\
31.6 \pm 0.4\end{array}$ & $\begin{array}{l}33.4 \pm 0.3 \\
31.6 \pm 0.3 \\
34.4 \pm 0.2 \\
33.8 \pm 0.2 \\
34.7 \pm 0.1 \\
32.1 \pm 0.4 \\
33.7 \pm 0.8 \\
34.1 \pm 0.2 \\
31.3 \pm 0.2 \\
35.1 \pm 0.2\end{array}$ \\
\hline
\end{tabular}

The arithmetic mean of all readings of all patients:

Before treatment in the climatic laboratory: $30 \cdot 6 \pm 0.4$. During treatment in the climatic laboratory: $33 \cdot 4 \pm 0.3$. Difference: $2 \cdot 8 \pm 0 \cdot 5$.

Difference between the increase of temperature of the thumb and the upper arm during the treatment in the climatic laboratory: $2 \cdot 3 \pm 0 \cdot 7$.

In the hot-room this skin-temperature rose, though much more on hands, feet, and distal parts of the extremities (just as far as the effect of the arterio-venous anastomosis reaches) than on the trunk, so that the difference has been inverted, warmer skin-temperature occurring on the distal parts than on the central. The peripheral vasospasm has been converted into peripheral vasodilatation. The peripheral circulation has increased, and the arteriovenous anastomoses especially have been maximally dilated.

A very interesting point is that, besides the consensual reaction of the vessels against, for example, ice on the skin, the inhalation of amyl nitrite, etc., in the warm-room is lowered or in some cases is inhibited (Tables 3 and 4, Figs. 4 and 5). The effect of the relative oxygen saturation of venous blood runs a parallel course.

At an ordinary room temperature of $20^{\circ} \mathrm{C}$. oxygen unsaturation of venous blood, measured at the median cubital vein, was, on an average of 12 patients in 20 determinations, 8.22 vol. per cent. $\pm 1 \cdot 11$, or 51 per cent. mean oxygen saturation. That is a low saturation. In normal individuals Lundsgaard (1918) found an oxygen saturation of 68 per cent. under the same conditions, and several other authors have found values that have also been around 70 per cent. (Liljestrand, 1928). This relatively low oxygen saturation in the venous blood can no doubt also be considered in association with the constricted peripheral circulation in these arthritic patients (Fig. 6). 

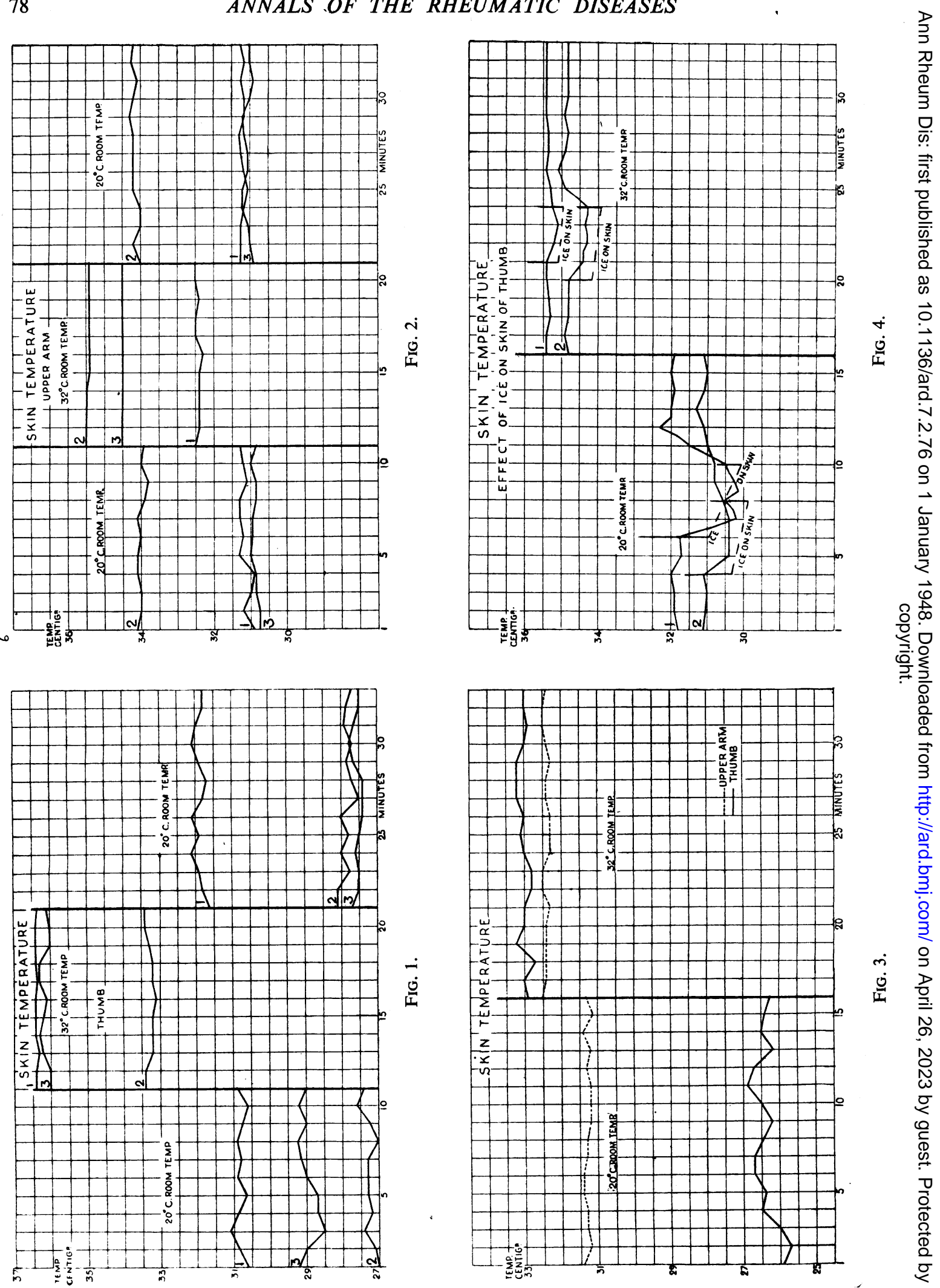
TABLE 3

INFLUENCE UPON THE TEMPERATURE OF ONE THUMB WHEN COOLING THE OTHER HAND IN ICE WATER BEFORE AND DURING THE TREATMENT IN THE CLIMATIC LABORATORY

\begin{tabular}{c|c|c}
\hline Patient & Before $\left({ }^{\circ} \mathrm{C}.\right)$ & During $\left({ }^{\circ} \mathrm{C}.\right)$ \\
\hline 1 & $-0.9 \pm 0.04$ & $-0.1 \pm 0.09$ \\
2 & $-0.3 \pm 0.09$ & $-0.0 \pm 0.03$ \\
3 & $-0.2 \pm 0.05$ & $-0.0 \pm 0.03$ \\
4 & $-0.7 \pm 0.09$ & $-0.1 \pm 0.06$ \\
5 & $-0.7 \pm 0.06$ & $-0.3 \pm 0.07$ \\
6 & $-1.0 \pm 0.12$ & $-0.2 \pm 0.06$ \\
7 & $-0.6 \pm 0.06$ & $-0.0 \pm 0.03$ \\
8 & $-0.7 \pm 0.06$ & $-0.0 \pm 0.03$ \\
9 & $-0.9 \pm 0.06$ & $-0.1 \pm 0.03$ \\
10 & $-1.1 \pm 0.06$ & $-0.0 \pm 0.05$ \\
\hline
\end{tabular}

The arithmetic mean of all the readings :

Alteration of temperature before treatment in the climatic laboratory : $-0.7 \pm 0.07$.

Alteration of temperature during treatment in the climatic laboratory: $-0 \cdot 1 \pm 0.06$.

Difference: $0.6 \pm 0.06$.

TABLE 4

INFLUENCE UPON THE TEMPERATURE OF THE THUMB OF INHALATION OF AMYL NITRITE BEFORE AND DURING TREATMENT IN THE CLIMATIC LABORATORY

\begin{tabular}{c|c|c}
\hline Patient & Before $\left({ }^{\circ} \mathrm{C}.\right)$ & During $\left({ }^{\circ} \mathrm{C}.\right)$ \\
\hline 3 & $-1.2 \pm 0.16$ & $-0.1 \pm 0.06$ \\
4 & $-0.3 \pm 0.08$ & $-0.0 \pm 0.00$ \\
5 & $-0.1 \pm 0.03$ & $-0.1 \pm 0.02$ \\
6 & $-0.9 \pm 0.17$ & $-0.0 \pm 0.06$ \\
7 & $-1.2 \pm 0.28$ & $-0.2 \pm 0.08$ \\
8 & $-0.9 \pm 0.12$ & $-0.1 \pm 0.01$ \\
9 & $-0.6 \pm 0.22$ & $-0.2 \pm 0.06$ \\
\hline
\end{tabular}

The arithmetic mean of all the readings:

Alteration of the temperature before treatment in the climatic laboratory: $0.7 \pm 0 \cdot 15$.

Alteration of the temperature during treatment in the climatic laboratory: $\mathbf{0} \cdot 1 \pm \mathbf{0 . 0 4}$

Difference: $0 \cdot 6 \pm 0 \cdot 15$.

At a room temperature of $32^{\circ} \mathrm{C}$. we found on an average of 6 patients in 24 determinations $2.92 \mathrm{vol}$. per cent. \pm 0.62 or 82 per cent. mean oxygen saturation (Edström, 1943). Goldschmidt and Light had observed that by keeping the forearm in hot water at a temperature of about $45^{\circ} \mathrm{C}$. a relative oxygen saturation could be established in the venous blood, measured in the same way in the cubital vein, of up to 92 per cent., that is, a value bordering on that of the arterial blood. By keeping the forearm in water at a temperature between $29^{\circ}$ and $39^{\circ} \mathrm{C}$. the authors were not able to obtain a higher oxygen saturation in these veins than 69 per cent., and by keeping it in air up to $32^{\circ} \mathrm{C}$, at most 75 per cent. The difference lies in the length of stay in the room, and also in the constancy of the temperature, this being the reason that a stronger effect was obtained by us.

The abnormally low saturation of the venous blood in these arthritic patients seems also to be a sign of the peripheral vasospasm. When this spasm vanished in the hot-room and was converted into vasodilatation, the saturation was good, and it seems that this maximal dilatation of the arteriovenous anastomoses is the reason for so high an oxygen saturation, approximating to the saturation of the arterial blood.

The venous blood taken from the cubital vein in the hot-room had a bright red colour which was at once noticeable, this being an observation similar to one made by many physicians in the tropics. This colour is caused by the high oxygen saturation of the blood, and we can thus confirm Mayer's hundred-year-old assumption. The haemoglobin was unchanged.

The cardiac output per minute (Table 5) was investigated before, during, and after the stay in the room. At normal heart function there were no statistically significant changes in it (Edström, 1944). In some cases with cardiac defect we obtained good compensating effect from the stay in the hot-room. It seems to be the diminished active peripheral resistance to blood flow at this higher temperature that is here of first importance (Wezler and Thauer, 1942).

Broadly speaking, no changes in calorie consumption and basal metabolic rate have been observed. However, there have been some individual variations (Edström, 1944) (Table 6, Fig. 7).

Thus, the so-called second chemical regulation of body-temperature has not begun to function at this temperature of $32^{\circ} \mathrm{C}$, at any rate in the majority of cases.

Cultures from the throat flora were regularly taken from all patients. In 24 of them (11 of the rheumatic-fever cases and 13 of the rheumatoidarthritis cases) these cultures on admission of the patients to the laboratory have shown $\beta$-haemolytic streptococci. In 22 of these, the cocci disappeared during the stay in the hot-room. Corresponding results have been obtained by removing persons from a temperate to a tropical climate (Coburn, 1931).

All cases treated in the laboratory were severe ones which had not improved earlier under ordinary internal and physical therapy.

The most obvious effects on the clinical symptoms were: remission of the periarticular oedema and 
TABLE 5

- THE CARDIAC OUTPUT PER MINUTE BEFORE AND DURING TREATMENT IN THE CLIMATIC LABORATORY

\begin{tabular}{c|c|c}
\hline Patient & Before (litres) & During (litres) \\
\cline { 2 - 3 } & $4.6 \pm 0.6$ & $4.3 \pm 0.2$ \\
5 & $4.9 \pm 0.6$ & $4.8 \pm 0.6$ \\
6 & $3.8 \pm 0.2$ & $4.1 \pm 0.2$ \\
7 & $5.1 \pm 0.2$ & $4.5 \pm 0.4$ \\
8 & $5.1 \pm 0.1$ & $4.8 \pm 0.2$ \\
9 & $3.6 \pm 0.2$ & $3.9 \pm 0.2$ \\
10 & $3.5 \pm 0.2$ & $3.0 \pm 0.0$ \\
\hline & & \\
\hline
\end{tabular}

The arithmetic mean of all the readings:

Before treatment in the climatic laboratory: $4.4 \pm 0.3$ litres

During treatment in the climatic laboratory: $4 \cdot 3 \pm 0.3$ litres.

Difference: $0.1 \pm 0.4$ litres.

the capsular swelling of the attacked joints, diminished shifting pains and contractures; after some days in the hot-room the patients could walk and move about much better and more easily, they had a larger appetite, and their weight went up; they had improved function in cases of cardiac defect, and the blue-livid coloration of the skin on hands and feet vanished.

Of the 16 rheumatic-fever cases, 13 improved, became entirely free from symptoms, and are at times capable of working. Ten of them, however, have deformities of their mitral valves. Two died of heart failure, and one of nephritis and uraemia.

Of the 18 rheumatoid arthritis cases, 8 became free from clinical symptoms and are at times entirely capable of work. Six improved, and 4 of these are at times working and in good condition; 2 had recurrence respectively one and $a$ half and three years after treatment in the warmroom. Two cases improved temporarily but deteriorated again. One case improved during the first treatment but had a relapse after return home four months later and could not be influenced by renewed treatment in the ward. In one case the treatment was broken off.

Tendency to recurrence immediately after removal back to ordinary room temperature was in no case observed.

Thus, there are three things we have especially found to
TABLE 6

THE BASAL METABOLISM BEFORE AND DURING TREATMENT IN THE CLIMATIC LABORATORY

\begin{tabular}{c|c|c}
\hline Patient & Before (calories) & During (calories) \\
\hline 4 & $1.03 \pm 0.08$ & $0.95 \pm 0.05$ \\
5 & $0.94 \pm 0.00$ & $0.89 \pm 0.04$ \\
6 & $0.97 \pm 0.04$ & $0.92 \pm 0.06$ \\
7 & $1.12 \pm 0.07$ & $1.18 \pm 0.02$ \\
8 & $1.13 \pm 0.03$ & $1.13 \pm 0.01$ \\
9 & $0.92 \pm 0.03$ & $1.04 \pm 0.02$ \\
10 & $1.03 \pm 0.01$ & $1.07 \pm 0.03$ \\
\hline
\end{tabular}

The arithmetic mean of all the readings:

Before treatment in the climatic laboratory: $1.02 \pm 0.04$ cal.

During treatment in the climatic laboratory: $1.03 \pm 0.03$ cal.

Difference: $0.01 \pm 0.05 \mathrm{cal}$.

result from the stay of the patients in the dry, hot microclimate : changes in peripheral circulation, changes in oxygen saturation of the venous blood, and changes in the throat flora. It seems as if the bacteriological changes are the results of the physiological. From the observations made we can begin to understand why $\beta$-haemolytic streptococci in throat flora, and diseases caused by such streptococci are relatively uncommon in tropical climates. I say " tropical climate" and not " the tropics" since it is the climate and not the latitude that is of importance.

\section{Summary}

For the last six years we have had one ward in the Rheumatological Department of the University

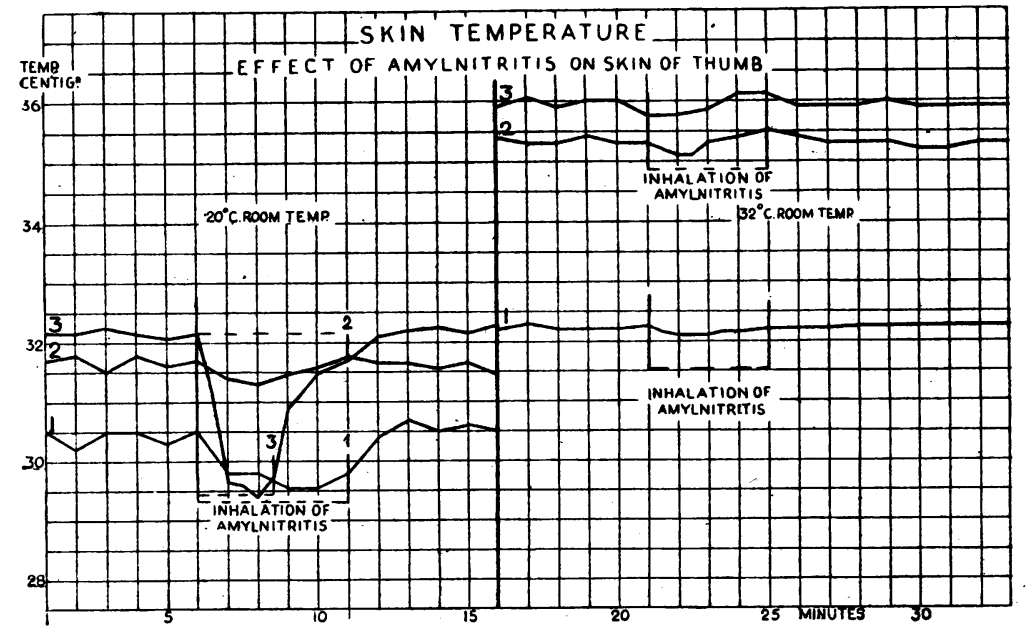

Fig. 5. 


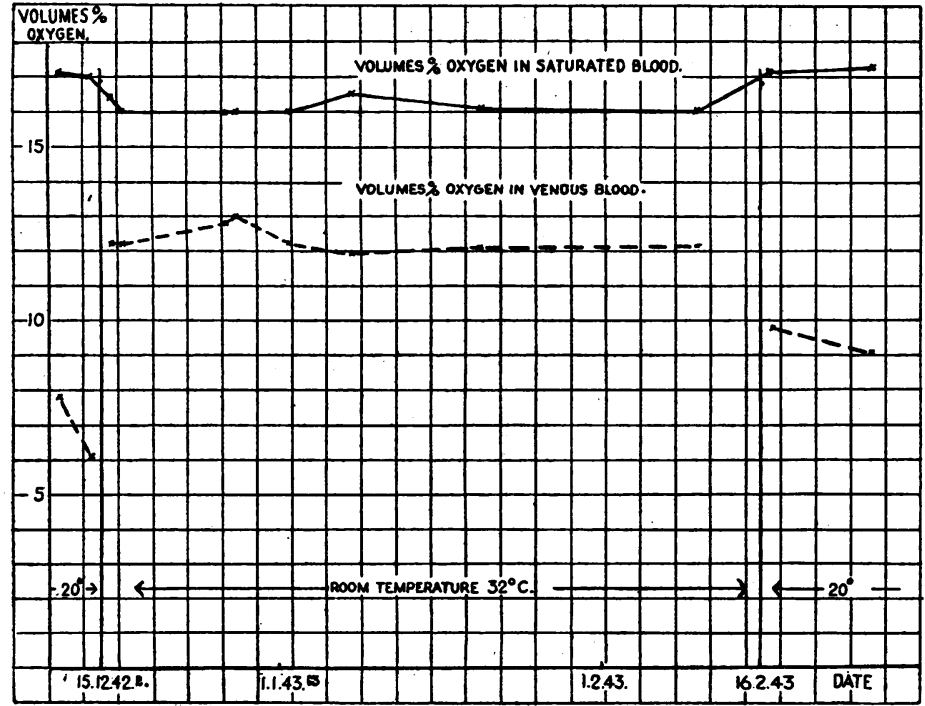

Fig. 6. venous difference diminished. At a room temperature of $20^{\circ} \mathrm{C}$. we obtained a 51 per cent. mean oxygen saturation, a very low saturation that can be considered in association with the constricted peripheral circulation in these patients also. In the hot-room the result was 82 per cent. mean oxygen saturation. Thus we may say that the bright red colour of venous blood in the tropics is caused by the high oxygen saturation of the blood. The haemoglobin was unchanged.

3. The cardiac output per minute showed no statistically signifcant changes in cases of normal heart function. In cases with cardiac defect the function of the heart was better, probably owing to a diminished active peripheral resistance to blood flow at the higher temperature.

Hospital in Lund constantly air-conditioned at $32^{\circ} \mathrm{C}$. and 35 per cent. relative humidity. In this ward we have treated arthritic patients, each of them for about a hundred days on an average.

The effect of the hot, dry microclimate on these patients is as follows:

1. The peripheral circulation increased in all. Peripheral vasospasm was converted into peripheral vasodilatation. The arteriovenous anastomoses especially have been maximally dilated. The temperature of the skin, which was lower at an ordinary room temperature of $20^{\circ} \mathrm{C}$. (especially in cases of rheumatoid arthritis) has been raised, particularly on hands, feet, and distal parts of the extremities, so far as the effect of the anastomoses has reached, where it has been higher than on more proximal parts on the trunk. In addition the consensual reaction of the vessels against, for example, ice on the skin, inhalation of amyl nitrite, etc., was lowered or failed to appear.

2: The relative oxygen saturation of venous blood, measured at the medial cubital vein increased in the hot-room, while the arterio-

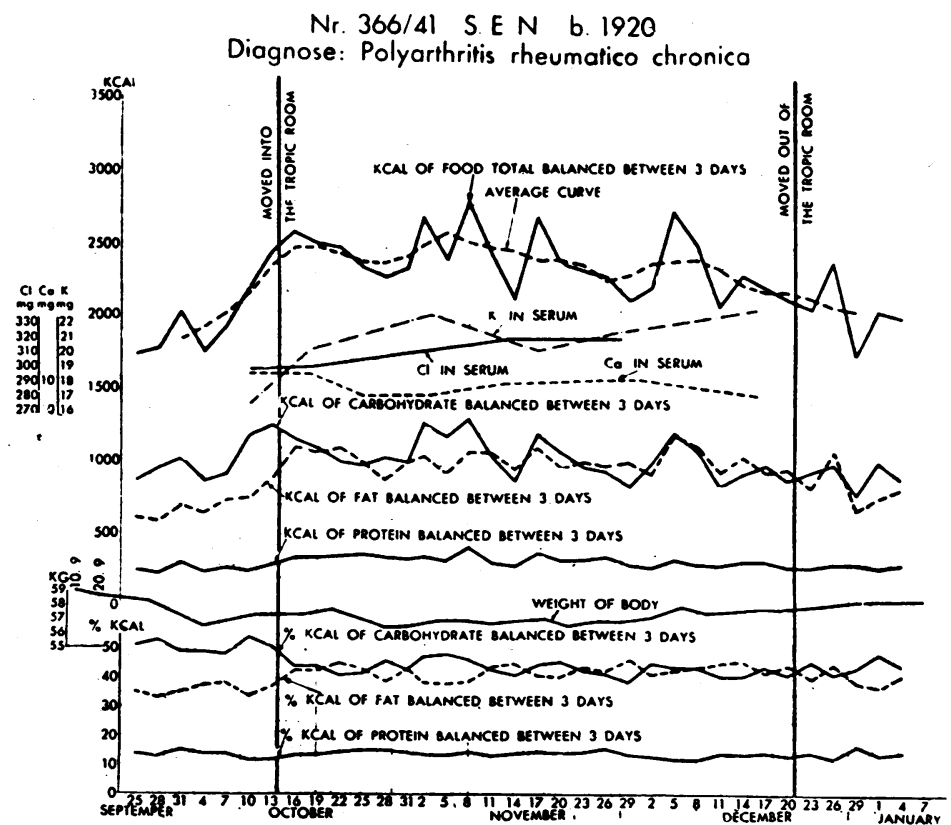

FIG. 7.

Nr. $366 / 41$ S. E N b. 1920
4. In most cases no changes in calorie consumption and basal metabolic rate could be observed. Thus, the so-called second chemical regulation of body temperature had not entered into function at this temperature of $32^{\circ} \mathrm{C}$. at any rate in the majority of cases.

 
5. Cultures from the throat flora showed in most cases $\beta$-haemolytic streptococci on admission of patients to the hot-room, but only in two cases were such cocci detected at the end of their stay. It seems as if these cocci do not tolerate this dry, hot climate in the room.

6. The most obvious effects on the clinical symptoms have been: remission of periarticular oedema and capsular swelling of attacked joints, diminished shifting pains and contractures, better appetite, improved function in cases of cardiac defects, and disappearance of the blue-livid coloration of skin on hands and feet.

Tendency to recurrence immediately after removal back into ordinary room temperature has in no case been observed.

\section{REFERENCES}

Coburn, A. F. (1931). " The Factor of Infection in the Rheumatic State." Baltimore.

Douglas, C. G. (1911). J. Physiol., 42, 17.

Edström, G. (1934). Acta med. scand., 83, 523.

(1940). Ibid., 103, 90.

(1943). Ibid., 114, 470.

(1944). Ibid., 117, 376.

Gagge, A. P., Herrington, L. P., and Winslow, C. E. A. (1937). Amer. J. Hyg., 26, 84.

Goldschmidt, S., and Light, B. (1925). J. biol. Chem., 64, 53.

Grollman, A. (1932). " The Cardiac Output in Health and Disease." Springfield.

Ipsen, J. (1936). “"Hauttemperaturen.” Köbenhavn.

Liljestrand, G. In Bethe, A. (1928). Handbuch norm. pathol. Physiol., Berlin, Bd. 6, no. 1, p. 452.

Lundsgaard, C. (1918). J. biol. Chem., 33, 133.

Slyke, D. D. van, and Neill, J. M. (1924). Ibid., 61, 554.

Wezler, K., and Thauer, R. (1942). Luftfahrtmed., 7, 228, 237.

Wright, L. M., and Pemberton, R. (1930). Arch. intern. Med., 45, 147.

\section{Examination des Effets du Microclimat Chaud et Sec sur les Malades Arthritiques, leur Circulation Périphérique, etc.}

\section{RÉSUMÉ}

Pendant les six dernières années une salle de la section de Rhumatologie de l'Hôpital de l'Université de Lund, a été constamment maintenue par conditionnement de l'air à $32^{\circ} \mathrm{C}$ et à 35 pour cent d'humidité relative. Dans cette salle nous avons traité des malades arthritiques, chacun d'eux pendant une durée moyenne de cent jours environ.
Les effets de ce microclimat chaud et sec sur ces malades sont les suivants:

1. La circulation périphérique augmente chez tous. Le vasospasme périphérique se transforme en vasodilatation. Les anastomoses artérioveineuses en particulier ont été dilatées au maximum. La température de la peau qui (particulièrement dans les cas d'arthrite rhumatismale) était basse à la température moyenne de $20^{\circ} \mathrm{C}$, s'est élevée, notamment pour les mains et les pieds, et les extrémités distales, aussi loin que l'action des anastomoses avait pu atteindre, là où elle avait été plus élevée que sur les parties plus proximales sur le tronc. De plus, la réaction des vaisseaux à des stimulants tels que glace sur la peau, inhalation de nitrite d'amyle, etc., était diminuée ou supprimée.

2. La saturation relative en oxygène du sang veineux, mesurée dans la veine cubitale, augmentait dans la salle chaude, tandis que la différence artérioveineuse diminuait. Dans une salle à $20^{\circ} \mathrm{C}$ nous obtenions une saturation moyenne de 51 pour cent, saturation très faible qui peut être considérée comme due à la vasoconstriction périphérique de ces malades. Dans la salle chaude le résultat était de 82 pour cent de saturation en oxygène. Nous pouvons donc dire que la coloration rouge vif du sang veineux sous les tropiques est due à la saturation élevée du sang en oxygène. L'hémoglobine n'était pas modifiée.

3. Le débit cardiaque par minute ne présentait aucune modification statistiquement significative dans les cas de fonctionnement normal du coeur. En cas de troubles cardiaques il y avait une amélioration due probablement à la diminution de la résistance périphérique active au flux sanguin à cette température élevée.

4. Dans la plupart des cas on n'a observé aucune modification dans la consommation en calories ou le métabolisme basal. Les soi-disant mécanismes de régulations chimiques secondaires de la température corporelle n'étaient pas entrés en jeu à cette température de $32^{\circ} \mathrm{C}$, du moins dans la majorité des cas.

5. Des cultures de la flore pharyngée présentèrent dans la plupart des cas du streptocoque hémolytique $\beta$ au moment de l'admission des malades dans la salle chaude, mais dans deux cas seulement ces cocci étaient encore présents à la fin du séjour. Il semble que ces cocci ne supportent pas l'atmosphère chaude et sèche de cette pièce.

6. Les effets les plus marqués sur les symptomes cliniques ont été: l'amélioration de l'oedème périarticulaire et de l'enflûre capsulaire des articulations atteintes, la diminution des douleurs fulgurantes et des contractures, l'amélioration de l'appétit, une amélioration fonctionnelle dans les cas de troubles cardiaques, et la diminution de la cyanose des extrémités.

On n'a observé dans aucun cas de tendance à la rechute aussitôt aprés le retour dans une salle à température normale. 